\title{
FROM WALL STREET TO BAY STREET
}

\author{
The Origins and Evolution of \\ American and Canadian Finance
}

When the 2008 financial crisis triggered a global recession, the American banking system experienced massive losses, takeovers, and taxpayer-funded bailouts. In contrast, the Canadian banking system managed to maintain its liquidity and profitability, ultimately withstanding the crisis relatively well. These divergent outcomes can be traced back to inherent differences between these two banking systems and their institutional and political histories.

From Wall Street to Bay Street is the first book written for a lay audience that tackles the similarities and differences between the financial systems of Canada and the United States. Christopher Kobrak and Joe Martin reveal the distinctive paths the two countries have taken since the early nineteenth century, despite their similar British colonial origins. The authors trace the roots of each country's financial system back to the time of Alexander Hamilton and Andrew Jackson and insightfully argue that while Canada has preserved a Hamiltonian financial tradition, the United States has favoured a populist Jacksonian tradition since the 1830s; as such, the innovative but erratic fashion in which the American system has changed over time is at odds with the more evolutionary and stable course taken by its Canadian counterpart. From Wall Street to Bay Street offers a timely and accessible comparison of financial systems that reflects the political and cultural milieus of two of the world's top ten economies.

The late CHRISTOPHER KOBRAK was a professor and the Wilson/Currie Chair of Canadian Business and Financial History at the Rotman School of Management and a professor of finance at ESCP Europe, Paris.

JOE MARTIN is the Director of the Canadian Business and Financial History Initiative at the Rotman School of Management as well as President Emeritus of Canada's History Society. 
This page intentionally left blank 

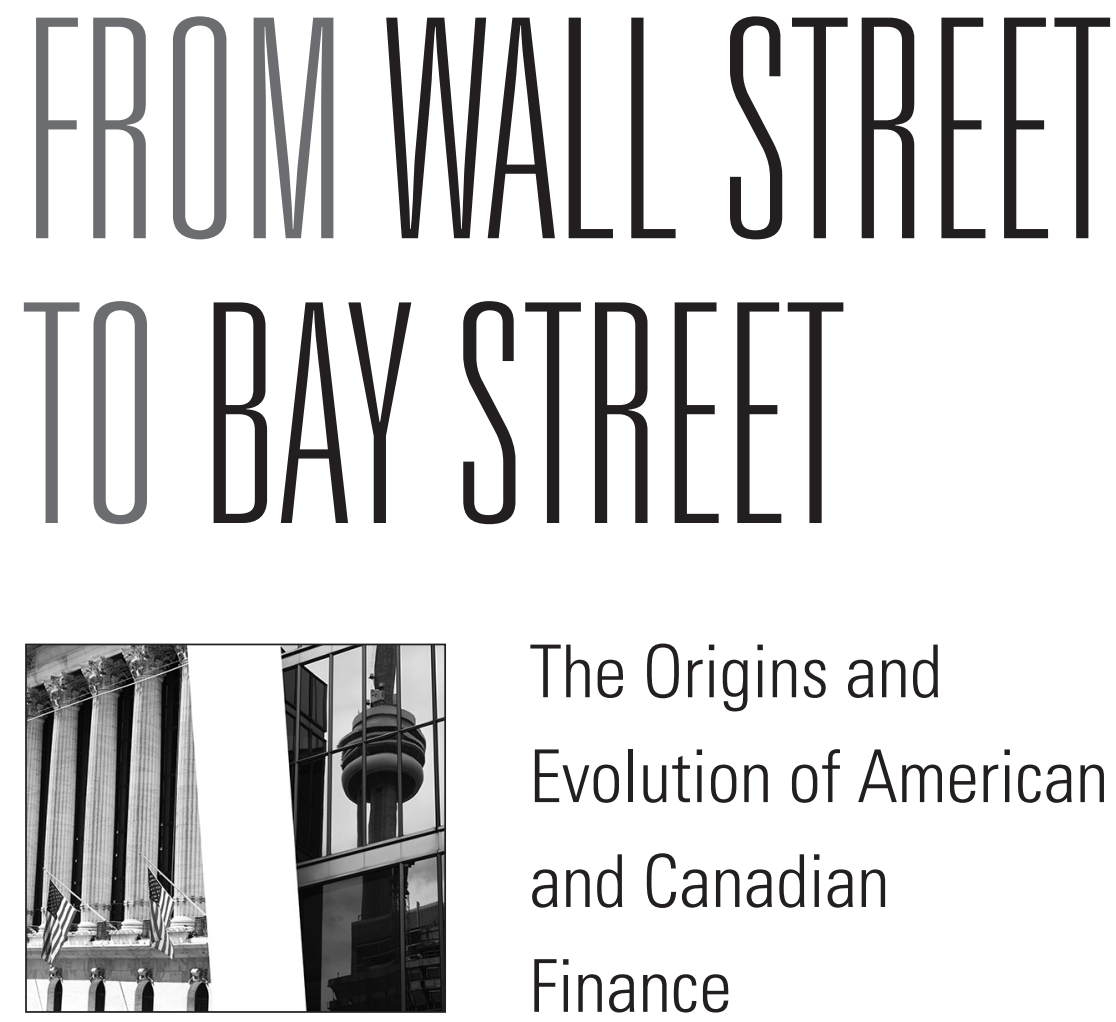

The Origins and

Evolution of American and Canadian

Finance

CHRISTOPHER KOBRAK AND JOE MARTIN

UNIVERSITY OF TORONTO PRESS

Toronto Buffalo London 
(C) University of Toronto Press 2018

Rotman-UTP Publishing

Toronto Buffalo London

utorontopress.com

Printed in Canada

ISBN 978-1-4426-4821-0 (cloth)

ISBN 978-1-4426-1625-7 (paper)

$(\infty)$

Printed on acid-free, 100\% post-consumer recycled paper with vegetable-based inks.

\section{Library and Archives Canada Cataloguing in Publication}

Kobrak, Christopher, author

From Wall Street to Bay Street : the origins and evolution of American and

Canadian finance / Christopher Kobrak, Joe Martin.

Includes bibliographical references and index.

ISBN 978-1-4426-4821-0 (cloth).--ISBN 978-1-4426-1625-7 (paper)

1. Finance - Canada - History - 2. Finance - United States - History

I. Martin, Joe, 1937-, author II. Title.

HG185.C2K63 2018

332.10971

C2017-908064-4

University of Toronto Press acknowledges the financial assistance to its publishing program of the Canada Council for the Arts and the Ontario Arts Council, an agency of the Government of Ontario.

Canada Council

for the Arts

\section{Conseil des Arts du Canada}

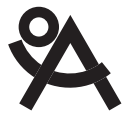

ONTARIO ARTS COUNCIL

CONSEIL DES ARTS DE L'ONTARIO

n Ontario government agency

un organisme du gouvernement de I'Ontario

Funded by the Financé par le Government gouvernement of Canada 
To our students: past, present, and future. 
This page intentionally left blank 